\title{
Evaluation of Different Cropping System Module under Irrigated Condition
}

\author{
Sirse Shreya ${ }^{1}$, S. M. Kurmavanshi ${ }^{2 *}$, R. Muniya ${ }^{1}$ and B. M. Maurya ${ }^{2}$ \\ ${ }^{1}$ All India Coordinated Research Project on Integrated Farming System, ${ }^{2}$ College of \\ Agriculture, JNKVV, Rewa (M.P.), 486001, India
}

\section{Keywords}

Cropping system

Rice equivalent yield, Intercropping

Article Info

Accepted:

10 November 2019

Available Online:

10 December 2019

\section{A B S T R A C T}

The field experiment on evaluation of different cropping system module in irrigated area was taken under All India Coordinated Research Project on Integrated Farming System during 2017-2018 to 2018-19. The study revealed that residual effect of rice-barley - bajra fodder cropping system was more as it gave grain yield of rice $51.44 \mathrm{q} / \mathrm{ha}$ followed by $51.17 \mathrm{q} / \mathrm{ha}$ in rice-gram + mustard-green manure cropping system. These cropping systems gave $14.7 \%$ to $15.31 \%$ higher yield of rice than existing rice-wheat system. Rice equivalent yield $222.48 \mathrm{q} / \mathrm{ha}$ was maximum in rice-garlic followed by $136.9 \mathrm{q} / \mathrm{ha}$ in rice-potato-green gram and $118.33 \mathrm{q} / \mathrm{ha}$ in ricegram+mustard-green manure cropping system. Net profit was maximum Rs.267732/ha in rice-garlic followed by Rs.184624/ha in rice-gram+ mustard-green manure and Rs.183745/ha. in rice-potato-green gram. Benefit cost ratio 3.6/ha was maximum in rice-gram+ mustard-green manure cropping system followed by 3.33 in rice-pea+ mustard-green manure while rice-garlic cropping system gave B:C ratio 2.49 .

\section{Introduction}

Rice-wheat, rice-gram and rice-barley are main cropping systems of Rewa region of Madhya Pradesh in rice-wheat crop zone. Rice-wheat cropping systems cover an area of 3.19 lakh ha. Rice-gram cropping system occupies 1.55 lakh hectares while rice-barley cropping systems are widely adopted by the farmer due to stable production and less labour requirement (Kumar et al., 2001). But continue adoption of these cropping systems had led to the problem of specific weeds, reduced soil fertility in specific root zone, development of soil sickness and infestation of similar kind of pest which ultimately resulted in decline the efficiency and productivity of system (Katyal 2003 and Kumar and Yadav 2005). The problem in further aggravated as irrigation facility in Rewa region of Madhya 
Pradesh is limited which affect the cultivation of wheat to a great extent. Rice-pea+mustard cropping systems are found most water efficient cropping system as compare to ricewheat and rice- barley existing cropping system. The inclusion of pulses, garlic, oil seed and vegetable in rabi season are found more beneficial than cereal after cereal (Kumpawat 2001). Rice is predominated crop in Rewa region of Madhya Pradesh.

It is difficult to replace the rice by other crop in rainy season due to soil and climatic condition. Hence only option left is to replace the wheat or gram or barley in winter by crops like garlic, potato, Toria-onion, Berseem to fulfill the needs of soil health, human nutrition, income generation and livestock for sustainable resource management under existing climatic condition of Rewa region of Madhya Pradesh. Different cropping systems module based on rice has not been evaluated. Keeping above facts in view present experiment was taken.

\section{Materials and Methods}

The study was made under All India Coordinated Research Project on Integrated farming system, Kuthulia farm of JNKVV, college of Agriculture Rewa (M.P.) during 2017-18 and 2018-19. The soil of experimental field was silty clay loam in texture, neutral in reaction $(\mathrm{pH} \mathrm{7.1)}$, low in organic carbon $(0.39 \%)$, low in available nitrogen $(163.83 \mathrm{~kg} / \mathrm{ha})$, medium in available phosphorus $(16.33 \mathrm{~kg} / \mathrm{ha})$ and available potash $219.7 \mathrm{~kg} / \mathrm{ha}$.

Ten cropping systems (Rice-wheat, rice-green manure-Barley, rice-gram+mustard (3:1)green manure, rice-pea-green gram, ricepotato-green gram, rice-pea+mustard, riceberseem, rice-barley-Bajra fodder, rice-garlic and rice-toria-onion were taken in Randomized block design with three replication. All the recommended package of practices for irrigated conditions were adopted. Immediately harvest of previous crop succeeding crops was sown under different cropping systems.

\section{Results and Discussion}

\section{Effect of cropping system on rice}

The grain yield of rice in response to residual effect of different cropping system has been presented in Table 1. It is evident from the Table that grain yield of rice $51.44 \mathrm{q} /$ ha was maximum in rice-barley-Bajra fodder cropping system followed by $51.17 \mathrm{q} / \mathrm{ha}$ in rice-gram-mustard-green manure cropping system. These cropping system gave $14.7 \%$ to $15.31 \%$ higher grain yield of rice than existing rice-wheat cropping system. Grain yield of rice was also increased by $6.45 \%$ in rice-green manure-Barley, $9.88 \%$ in rice-pea-green gram, $8.97 \%$ in rice-potato-green gram and $8.2 \%$ in rice-toria-onion cropping system. It may be due to positive residual effect preceding rabi and summer crops like green manure- barleybajra-potato- green gram and toria- onion by which growth and yield contributing character of rice were higher as compared to existing rice-wheat cropping system. It may also be due to amelioration of organic carbon in soil and available nitrogen and Potash. Combine effect of all these had positive effect on performance of rice by which grain yield of rice was increased considerably. The positive effect of preceding Berseem, green manure, mustard, potato and gram + mustard was also reported by Sharma and Jain (1997), Yadav et al., (2014), Chouriya (2016) and Jugnahake et $a l$. , (2018). The grain yield of rice $42.59 \mathrm{q} / \mathrm{ha}$ was minimum in rice-garlic cropping system followed by $44.49 \mathrm{q} / \mathrm{ha}$ in rice-pea+mustard cropping system. Grain yield of rice was reduced by $2.69 \%$ to $5.82 \%$ in comparison to existing rice-wheat cropping system but were at par to existing rice-wheat cropping system. 


\section{Effect on Rice equivalent}

The productivity of individual crop component of different nature under any cropping system have its own importance to contribute the productivity of entire cropping system. Thus it is possible to asses the productivity of any cropping system with the productivity of only and individual crop component. Therefore combine yield of different kharif and rabi crops grown under cropping sequence converted to rice equivalent yield on the basis of prevailing market price of the produce for an individual crop component under a particular cropping system play an important role on the rice equivalent yield. The rice equivalent yield is presented in Table 2. It is clear from the result that all the cropping system gave $3.91 \%$ to $147.7 \%$ higher rice equivalent yield than existing rice-wheat cropping system. Rice equivalent yield was reduced by $2 \%$ in ricepea-green gram cropping system. The maximum rice equivalent yield $222.48 \mathrm{q} / \mathrm{ha}$ was noted in rice-garlic followed by $136.9 \mathrm{q} / \mathrm{ha}$ in rice-potato-green gram and $118.33 \mathrm{q} / \mathrm{ha}$ in rice-gram+mustard-green manure cropping system. These cropping system were found significantly superior than all other cropping system. The similar result were also reported by Jugnahake et al., (2018).

\section{Effect on gross and net return}

Data pertaining to Gross and Net profit of different cropping system module have been given in Table 2. After perusal of the result it is clear that minimum gross return Rs. $159812 / \mathrm{ha}$ was in rice-pea-green gram followed by Rs. 161644/ha in existing ricewheat cropping system. All other cropping system gave $3.93 \%$ to $147.74 \%$ higher gross return in comparison to existing rice-wheat system. Similarly Net profit of different cropping system were higher by $2 \%$ to
$120.31 \%$ and maximum net profit Rs. 267732/ha was noted in rice-garlic followed by Rs. 184624/ha in rice-gram+mustard-green manure and Rs. 183745/ha. in rice-potatogreen gram cropping system. These cropping system gave $51.2 \%$ to $120.31 \%$ higher net profit than existing rice-wheat cropping system. It may be due to higher yield and higher marketable price with more investment gave higher net return. Similar finding were also reported by Mourya et al., (2011) and Jugnahake (2018).

Benefit: Cost ratio under different cropping system module is given in Table 2. Reveals that $\mathrm{B}: \mathrm{C}$ ratio 3.60 was maximum in ricegram+ mustard-green manure cropping system followed by 3.33 in rice-berseem, 3.28 in ricepea +mustard- green manure while rice-garlic cropping system gave $\mathrm{B}: \mathrm{C}$ ratio 2.49 . The $\mathrm{B}: \mathrm{C}$ ratio of rice-pea-green gram and rice-toriaonion was lower than existing rice-wheat system on the basis of Per rupee investment.

\section{Effect on chemical properties of soil}

The chemical properties of soil after completion of three crop cycle have been given in Table 3. Which reveals that soil $\mathrm{pH}$ and electrical conductivity were almost normal as compare to initial status. Organic carbon status was found to increase by $7.69 \%$ to $38.46 \%$ under rice-green manure-barley, rice-gram+ mustard-green manure, rice-peagreen gram, rice-potato-green gram, rice-pea +mustard-green manure, rice-berseem and rice-barley-bajra fodder cropping system while organic carbon status was reduced in rice-garlic cropping system by $2.56 \%$ and in rice-toria-onion by $5.12 \%$ as compared to initial status. It may be due to addition of green manure, pulses, berseem and other crops which add more organic matter into soil as compared to rice-garlic and rice-toria-onion cropping system. 
Table.1 Economical yield of kharif rabi and summer crops under different cropping system module

\begin{tabular}{|c|c|c|c|c|c|c|c|c|c|}
\hline Treatment & & & & Yield & q/ha & & & & \\
\hline & Kharif & & Mean & Rabi & & Mean & Rabi/ & Summer & Mean \\
\hline & $\begin{array}{c}2017- \\
18\end{array}$ & $\begin{array}{c}2018- \\
19\end{array}$ & & $\begin{array}{c}2017- \\
18\end{array}$ & $\begin{array}{c}2018- \\
19\end{array}$ & & $\begin{array}{l}2017- \\
18\end{array}$ & 2018-19 & \\
\hline T $_{1}$ Rice(Danteshwari)-Wheat(HD 02864) & 50.29 & 38.94 & 44.61 & 55.53 & 56.3 & 55.91 & & & \\
\hline $\mathbf{T}_{2}$ Rice(Danteshwari)-Green manure-Barley(Geetanjali) & 54.54 & 40.45 & $\begin{array}{c}47.49 \\
(6.45 \%)\end{array}$ & 146.6 & 128.4 & 137.5 & 56.62 & 55.1 & 55.86 \\
\hline $\begin{array}{l}\text { T }_{3} \text { Rice(Danteshwari)-Gram(JG-322)+Mustard(Pusa bold)- } \\
\text { GM }\end{array}$ & 56.62 & 45.73 & $\begin{array}{c}51.17 \\
(14.70 \%)\end{array}$ & $\begin{array}{l}13.43 \\
23.23\end{array}$ & $\begin{array}{l}12.3 \\
19.9\end{array}$ & $\begin{array}{l}12.86 \\
21.56\end{array}$ & 125.9 & 132.2 & 129.05 \\
\hline $\mathrm{T}_{4}$ Rice(Danteshwari)-Pea(Arkel)-Green gram(PDM)-139) & 53.91 & 44.13 & $\begin{array}{c}49.02 \\
(9.88 \%)\end{array}$ & 82.14 & 60.9 & 71.52 & 9.16 & 11.9 & 10.53 \\
\hline $\begin{array}{l}\text { T}_{5} \text { Rice(Danteshwari)-Potato (Kufrichandramukhi) -Green } \\
\text { gram }\end{array}$ & 54.97 & 42.19 & $\begin{array}{c}48.58 \\
(8.97 \%)\end{array}$ & 219.23 & 193.4 & 206.31 & 7.86 & 10.66 & 9.26 \\
\hline $\begin{array}{l}\text { T}_{6} \text { Rice(Danteshwari)-Pea (Arkel)+ Mustard (Pusa bold)- } \\
\text { Green manure }\end{array}$ & 50.63 & 38.36 & $\begin{array}{c}44.49 \\
-(2.69 \%)\end{array}$ & $\begin{array}{l}19.00 \\
15.05\end{array}$ & $\begin{array}{l}14.2 \\
17.3\end{array}$ & $\begin{array}{c}16.6 \\
16.17\end{array}$ & 116.8 & 129.3 & 123.05 \\
\hline T $_{7}$ Rice(PS-5)-Berseem(JB-1) & 45.84 & 47.27 & $\begin{array}{c}46.55 \\
(4.34 \%)\end{array}$ & 751.73 & 721.9 & 736.81 & 1.5 & 3.4 & 2.45 \\
\hline $\begin{array}{l}\text { T8Rice(Danteshwari)-Barley fodder(JB-58) Bajra fodder } \\
\text { (WCC-75) }\end{array}$ & 57.04 & 45.84 & $\begin{array}{c}51.44 \\
(15.31 \%)\end{array}$ & 458.73 & 568.6 & 513.66 & 502.33 & 490.1 & 496.21 \\
\hline T9Rice(PS-5)-Garlic (G-1) & 42.06 & 43.12 & $\begin{array}{c}42.59 \\
-(5.52 \%)\end{array}$ & 131.55 & 150.2 & 140.87 & - & - & - \\
\hline T $_{10}$ Rice(Danteshwari)-Toria(T-9)-Onion & 56.18 & 40.36 & $\begin{array}{c}48.27 \\
(8.20 \%)\end{array}$ & 7.86 & 9.3 & 8.58 & 173.5 & 193.7 & 183.6 \\
\hline SEM \pm & 1.13 & 1.50 & 1.31 & & & & & & \\
\hline CD at $5 \%$ & 3.13 & 4.44 & 3.89 & & & & & & \\
\hline
\end{tabular}

Figures in parenthesis are \% increase/decrease over rice- wheat system. 
Table.2 Rice equivalent yield, gross and net return Rs/ha. And B:C ratio under different cropping system module

\begin{tabular}{|c|c|c|c|c|c|c|}
\hline \multirow[t]{2}{*}{ Treatment } & \multicolumn{2}{|c|}{ REY q/ha } & \multirow[t]{2}{*}{ Mean } & \multirow{2}{*}{$\begin{array}{c}\text { Gross } \\
\text { return } \\
\text { Rs/ha }\end{array}$} & \multirow{2}{*}{$\begin{array}{c}\text { Net } \\
\text { Profit } \\
\text { Rs/ha }\end{array}$} & \multirow{2}{*}{$\begin{array}{l}\text { B:C } \\
\text { ratio }\end{array}$} \\
\hline & $\begin{array}{c}2017- \\
18\end{array}$ & $\begin{array}{c}\text { 2018- } \\
19\end{array}$ & & & & \\
\hline $\mathrm{T}_{1}$ Rice (Danteshwari)-Wheat (HD 02864) & 117.67 & 61.93 & $\begin{array}{c}89.8 \\
(0.00)\end{array}$ & 161644 & 121521 & 2.55 \\
\hline $\mathbf{T}_{2}$ Rice (Danteshwari)-Green manure- Barley (Geetanjali) & 129.73 & 71.81 & $\begin{array}{c}100.77 \\
(12.21 \%)\end{array}$ & 181389 & $\begin{array}{l}142144 \\
(16.97)\end{array}$ & 2.91 \\
\hline $\begin{array}{l}\text { T }_{3} \text { Rice (Danteshwari)-Gram (JG-322) + Mustard (Pusa bold)- } \\
\text { GM }\end{array}$ & 151.52 & 85.15 & $\begin{array}{c}118.33 \\
(31.77 \%)\end{array}$ & 213004 & $\begin{array}{l}184624 \\
(51.92)\end{array}$ & 3.90 \\
\hline $\mathrm{T}_{4}$ Rice (Danteshwari)-Pea (Arkel)-Green gram (PDM)-139) & 117.66 & 59.90 & $\begin{array}{c}88.78 \\
-(1.13 \%)\end{array}$ & 159812 & $\begin{array}{c}123152 \\
(1.34)\end{array}$ & 2.52 \\
\hline $\begin{array}{l}\text { T }_{5} \text { Rice (Danteshwari)-Potato (Kufrichandramukhi) -Green } \\
\text { gram }\end{array}$ & 165.06 & 108.75 & $\begin{array}{c}136.90 \\
(52.44 \%)\end{array}$ & 246446 & $\begin{array}{l}183745 \\
(51.20)\end{array}$ & 2.92 \\
\hline $\begin{array}{l}\text { T}_{6} \text { Rice (Danteshwari)-Pea (Arkel)+ Mustard (Pusa bold)- } \\
\text { Green manure }\end{array}$ & 124.33 & 72.7 & $\begin{array}{c}98.51 \\
(9.69 \%)\end{array}$ & 177334 & $\begin{array}{l}144275 \\
(18.72)\end{array}$ & 3.28 \\
\hline T $_{7}$ Rice (PS-5)-Berseem (JB-1) & 128.78 & 78.78 & $\begin{array}{c}103.78 \\
(15.56 \%)\end{array}$ & 186822 & $\begin{array}{l}166978 \\
(37.40)\end{array}$ & 3.33 \\
\hline $\begin{array}{l}\text { T }_{8} \text { Rice (Danteshwari)-Barley fodder (JB-58) Bajra fodder } \\
\text { (WCC-75) }\end{array}$ & 98.80 & 87.84 & $\begin{array}{c}93.32 \\
(3.91 \%)\end{array}$ & 167998 & $\begin{array}{c}145145 \\
19.44\end{array}$ & 3.07 \\
\hline T9 Rice (PS-5)-Garlic (G-1) & 195.64 & 249.33 & $\begin{array}{c}222.48 \\
(147.7 \%)\end{array}$ & 400473 & $\begin{array}{l}267732 \\
(120.31)\end{array}$ & 2.49 \\
\hline $\mathbf{T}_{10}$ Rice (Danteshwari)-Toria(T-9)-Onion & 148.69 & 105.86 & $\begin{array}{c}127.27 \\
(41.72 \%)\end{array}$ & 229098 & $\begin{array}{c}130996 \\
(7.79)\end{array}$ & 1.78 \\
\hline SEM \pm & 2.5 & 3.72 & 3.11 & & & \\
\hline CD at $5 \%$ & 7.40 & 11.01 & 9.20 & & & \\
\hline
\end{tabular}

Figures in parenthesis are \% over rice-wheat system. 
Table.3 Chemical properties of soil after completion of three crop cycle

\begin{tabular}{|c|c|c|c|c|c|c|}
\hline Treatment & pH & $\begin{array}{c}\text { EC } \\
\text { Mmhos } / \mathrm{cm}^{-1}\end{array}$ & OC g/kg & $\begin{array}{l}\text { N avail. Kg } \\
\text { /ha }^{-1}\end{array}$ & $\begin{array}{l}\text { P avail. } \\
\mathrm{Kg} / \mathrm{ha}^{-1}\end{array}$ & $\begin{array}{l}\text { K avail. Kg } \\
\text { /ha }^{-1}\end{array}$ \\
\hline $\mathrm{T}_{1}$ Rice (Danteshwari)-Wheat (HD 02864) & 7.3 & 0.21 & $0.39(0)$ & $112.69(-3.12)$ & $\begin{array}{l}10.2(- \\
37.53)\end{array}$ & $372(69.32)$ \\
\hline $\begin{array}{l}\mathbf{T}_{2} \text { Rice (Danteshwari)-Green manure- Barley } \\
\text { (Geetanjali) }\end{array}$ & 6.6 & 0.26 & $0.42(7.69)$ & $106.2(-35.16)$ & $\begin{array}{l}11.7(- \\
28.35)\end{array}$ & $368(67.50)$ \\
\hline $\begin{array}{l}\text { T3 Rice (Danteshwari)-Gram (JG-322) + } \\
\text { Mustard (Pusa bold)-GM }\end{array}$ & 6.7 & 0.28 & $0.58(48.71)$ & $198.4(21.12)$ & $\begin{array}{l}14.2(- \\
13.04)\end{array}$ & $416(89.34)$ \\
\hline $\begin{array}{l}\text { T }_{4} \text { Rice (Danteshwari)-Pea (Arkel)-Green } \\
\text { gram (PDM)-139) }\end{array}$ & 7.3 & 0.41 & $0.47(20.51)$ & $197.9(20.81)$ & $\begin{array}{l}13.8(- \\
15.49)\end{array}$ & $380.5(73.19)$ \\
\hline $\begin{array}{l}\mathbf{T}_{5} \text { Rice (Danteshwari)-Potato } \\
\text { (Kufrichandramukhi) -Green gram }\end{array}$ & 6.6 & 0.48 & $0.46(17.94)$ & $116.3(-28.99)$ & $\begin{array}{l}12.6(- \\
22.84)\end{array}$ & $295.4(34.45)$ \\
\hline $\begin{array}{l}\text { T}_{6} \text { Rice (Danteshwari)-Pea (Arkel)+ Mustard } \\
\text { (Pusa bold)-Green manure }\end{array}$ & 6.4 & 0.33 & $0.48(23.07)$ & $119.4(-27.10)$ & $\begin{array}{l}14.3(- \\
12.63)\end{array}$ & $332.4(51.29)$ \\
\hline T $_{7}$ Rice (PS-5)-Berseem (JB-1) & 6.2 & 0.41 & $0.52(33.33)$ & $123.6(-24.54)$ & $16.2(-0.79)$ & $410.6(86.89)$ \\
\hline $\begin{array}{l}\text { T}_{8} \text { Rice (Danteshwari)-Barley fodder (JB-58) } \\
\text { Bajra fodder (WCC-75) }\end{array}$ & 7.9 & 0.32 & $0.54(38.46)$ & $181.2(10.62)$ & $15.3(-6.30)$ & $418.3(90.39)$ \\
\hline T, $_{9}$ Rice (PS-5)-Garlic (G-1) & 6.7 & 0.38 & $0.38(-2.56)$ & $132.8(-18.92)$ & $16.0(-2.02)$ & $381.8(73.78)$ \\
\hline $\mathrm{T}_{10}$ Rice (Danteshwari)-Toria(T-9)-Onion & 7.2 & 0.69 & $0.37(-5.12)$ & $136.2(-16.84)$ & $\begin{array}{l}13.5(- \\
17.33)\end{array}$ & $363.7(65.54)$ \\
\hline Initial & 7.1 & 0.5 & 0.39 & 163.8 & 16.33 & 219.7 \\
\hline
\end{tabular}

Figures in parenthesis are \% increase (+) 0r decrease (-) over initial 
Available nitrogen status after completion of three crop cycle is given in Table 3 reveals that available nitrogen status was increased by $10.62 \%$ to $21.12 \%$ in rice-gram +mustardgreen manure, rice-pea-green gram and ricebarley- bajra fodder cropping system as compared to initial status. Available nitrogen status in all other cropping system was reduced by $3.12 \%$ to $35.16 \%$ as compared to initial status under different cropping system and maximum reduction in available phosphorus was noted in rice-wheat cropping system as compared to initial status. Available potash status was increased by $34.45 \%$ to $89.34 \%$ over initial status. Similar result were also reported by Jugnahake et al.,(2018).

On the basis of present field experiment that rice-garlic, rice-potato-green gram and ricegram +mustard cropping system were found more remunerative for income generation and family nutrition while rice-barley- bajra fodder cropping system gave more fodder yield for livestock raising than rice- berseem cropping system. These cropping system were also found superior than rice-wheat and ricebarley existing cropping system.

\section{References}

Chouriya SR, Chouhan M, Kurmanvanshi SM and Maurya BM. 2016. Performance of different Bio-Intensive need based cropping systems under irrigated condition. Mysore journal of Agriculture Science 50(4):716-720.

Jugnahake M, Prajapat R, Maurya BM and Kurmavanshi SM. 2018. Identification of Cropping system module for irrigated farming system of Rewa region. International Journal of Current microbiology and applied science 7(10): 678-694.

Katyal JC. 2003. Soil fertility management A key to prevent diversification, Journal of the Indian Society of soil Science 51(2): 379-387.

Kumar A and Yadav DS. 2005. Influence of continuous cropping and fertilization on nutrient availability and productivity of an alluvial soil. Journal of the Indian Society of soil science 53(2): 194-198.

Kumar A, Yadav DS, Singh RM and Achal R. 2001. Productivity, Profitability and stability of (Oryza sativa) based cropping system in eastern Utter Pradesh. Indian Journal of Agronomy 46(4): 576-577.

Kumpawat BS, 2001. Production potential and economics of different crop sequence. Indian Journal Agronomy 46(3): 421424.

Maurya BM, Upadhyay VB and Mishra Sandhya.2011. Crop diversification based on rice in Kymoresatpura agroclimatic zone of Madhya Pradesh. Mysore Journal of Agriculture science 45(4): 916-917.

Sharma RS and Jain KK. 1997. Agronomic research advance in rice-wheat system in M.P. Advances in Agricultural Research in India 7: 139-157.

Yadav PS, Maurya BM and Kurmavanshi SM. 2014. Growth and development of rice under different irrigated Cropping system. Mysore Journal of Agriculture science 48(3): 451-455.

\section{How to cite this article:}

Sirse Shreya, S. M. Kurmavanshi, R. Muniya and Maurya, B. M. 2019. Evaluation of Different Cropping System Module under Irrigated Condition. Int.J.Curr.Microbiol.App.Sci. 8(12): 982988. doi: https://doi.org/10.20546/ijcmas.2019.812.126 